\title{
Processes Governing the Retention of Phosphorus and Nitrogen in Nyashishi Wetland
}

\author{
Baraka C. Sekadendeㄹ, John F. Machiwa' ${ }^{2}$, Fredrick F. Mwanuzi ${ }^{3}$ \\ ${ }^{1}$ Tanzania Fisheries Research Institute, Kigoma, Tanzania \\ ${ }^{2}$ University of Dar es Salaam, Dar es Salaam, Tanzania \\ ${ }^{3}$ College of Engineering Science and Technology, Dar es Salaam, Tanzania \\ Email: bkdd1@yahoo.com
}

Received 26 November 2013; revised 27 December 2013; accepted 3 January 2014

Copyright (C) 2014 by authors and Scientific Research Publishing Inc.

This work is licensed under the Creative Commons Attribution International License (CC BY). http://creativecommons.org/licenses/by/4.0/

(c) (i) Open Access

\begin{abstract}
One of the important functions of the wetland is the retention of catchment nutrients and improving lacustrine water quality. This study analyzed how much nutrients were retained in the Nyashishi wetland, southern part of Lake Victoria, and went further to analyze the processes which were responsible in the reduction of nutrients. Three major processes were analysed in this study, namely nutrients uptake by three macrophyte species (Eichhornia crassipes, Cyperus papyrus and Typha domingensis) dominating the Nyashishi wetland, nitrification and denitrification processes. The study demonstrated high nutrients retention especially phosphorus nutrients of which up to $\mathbf{9 8 \%}$ were retained. In some occasions, particularly for nitrogen nutrients, there was $0 \%$ retention especially during wet season. In some other instances, the inflow exceeded the outflow meaning that, more nutrients were generated by the wetland itself. Among the three processes analyzed, nutrients uptaken by macrophytes were more efficient in reducing nutrients in wetland water. Biological nitrification and denitrification which are believed to be the major pathway for ammonia removal in both natural and constructed wetlands were less important in this study. Among the macrophyte species, Eichhornia crassipes demonstrated higher uptake rate than the other two species possibly due to its high turnover rate. This ability can be exploited in removing excess nutrients from runoff by frequent harvesting of the mature plants.
\end{abstract}

\section{Keywords}

Phosphorus; Nitrogen; Nitrification; Denitrification; Nutrients Uptake 


\section{Introduction}

Wetlands constitute an important part of the catchment area of Lake Victoria, and perform a number of beneficial roles that have direct consequences on the lake ecosystems [1]. One of the most important functions is the retention of catchment nutrients, such as nitrogen and phosphorus, thus maintaining and improving the lacustrine water quality [2]. Through the uptake of nutrients by wetland sediments and plants, and by sedimentation of nutrient-rich particulate matter, wetlands can act as buffers against Lake Eutrophication [1] [3]. Another identified fate of nutrients once they enter the wetland is loss through degassing, and direct flow through the wetlands [2].

Wetland macrophytes play an important role in removing nutrients through incorporation of nitrogen and phosphorus in plant tissue to produce plant biomass. If wetland macrophytes are sustainably harvested, this could form a permanent removal mechanism for nutrients and other substances incorporated in the plant tissue. Several macrophytes, such as Water hyacinth (Eichhornia crassipes), water lettuce (Pistia stratiotes) and duckweed (Lemnaceae) [4] have been reported for the efficiency removal of nutrients.

Particularly, nitrogen removal in the wetland is influenced by several factors, such as the type of macrophytes present in the wetland, sediment layers and the speed of incoming water. Transformation pathways are nitrification and denitrification, decomposition and mineralization of organic nitrogen. Biological nitrification, which is facilitated by nitrifiers, such as Nitrosomonas, Nitropira, Nitrosococcus and Nitrobacter followed by denitrification is believed to be the major pathway for ammonia removal in both natural and constructed wetlands [5].

Scanty information is available on the removal and transformation pathways of nitrogen and phosphorus in tropical natural wetlands [6] [7]. In the last decades, the human population around Lake Victoria has increased considerably. The population has grown from 4.6 million in 1932 to 27.7 million in 1995 and was estimated at 38 million in 2010 [8]. Currently, Mwanza region supports about 4 million people, with a population growth rate of 3.4\%. Such growth leads to increases in domestic and industrial waste and sewage water, firewood burning and agricultural land use [9]. Soil erosion and runoff are the consequences of the growing demand for agricultural land use, leading to increased nutrient input into the lake [9]. Atmospheric deposition and land runoff are responsible for approximately $90 \%$ and $94 \%$ of the phosphorous and nitrogen input into the lake [10]. Pollution loading to Lake Victoria due to urban waste water runoff was estimated to be 719 tons/year of total nitrogen and 292 tons/ year of total phosphorus; out of which 324 tons/year of total nitrogen and 208 tons/year of total phosphorus are from industrial loading [11]. This exerts substantial pressures on already inadequate sewage treatment systems. Nyashishi River alone has been reported to transport up to 62 tons/year total nitrogen and 11 tons/year of total phosphorus [11]. This has caused substantial phosphorus and nitrogen being washed into the lake. Consequently, eutrophication is increasingly continuing to become a significant issue in Lake Victoria [12] [13]. Thus, the presence of functional wetlands is a vital means of reducing the amount of phosphorus and nitrogen deposited in the Lake. The current study was designed to examine the removal capacity of the Nyashishi wetland, and the major processes governing the removal of nitrogen and phosphorus in the natural Nyashishi wetland. This information is necessary in order to fully utilize the potential of this wetland in maintaining the water quality of Lake Victoria.

\section{Materials and Methods}

\subsection{Study Area}

Nyashishi wetland is located on the western side of Lake Victoria some $15 \mathrm{~km}$ from Mwanza City. The area is characterized by a double maxima rainfall, with heavy rains occurring during October to December. The wetland is traversed by the Nyashishi River, which is an intermittent river draining stormy waters and domestic waste water into Lake Victoria. The wetland is lined with multiple macrophyte species such as Cyperus papyrus community and Typha domingensis with small patches of Phragmites mauritianus and mixed Cyperus-typha Figure 1. Samples for this study were drawn from the water inlet section (designated as SSW), which was mainly the river before entering the wetland, the within wetland section (Swamp), and the outlet which was located at the river mouth (OW). The distance from SSW to the outlet point was about $4 \mathrm{~km}$. Water samples for nutrients analysis were collected from the inlet (SSW) and outlet sites (OW), while the nitrification and denitrification experiments were conducted within the wetland (Swamp), (see Figure 1).

\subsection{Determination of Nutrients Retention in the Wetland}

Water samples for nutrients analysis were collected using a 2 litres Van Dorn opaque plastic water sampler. 


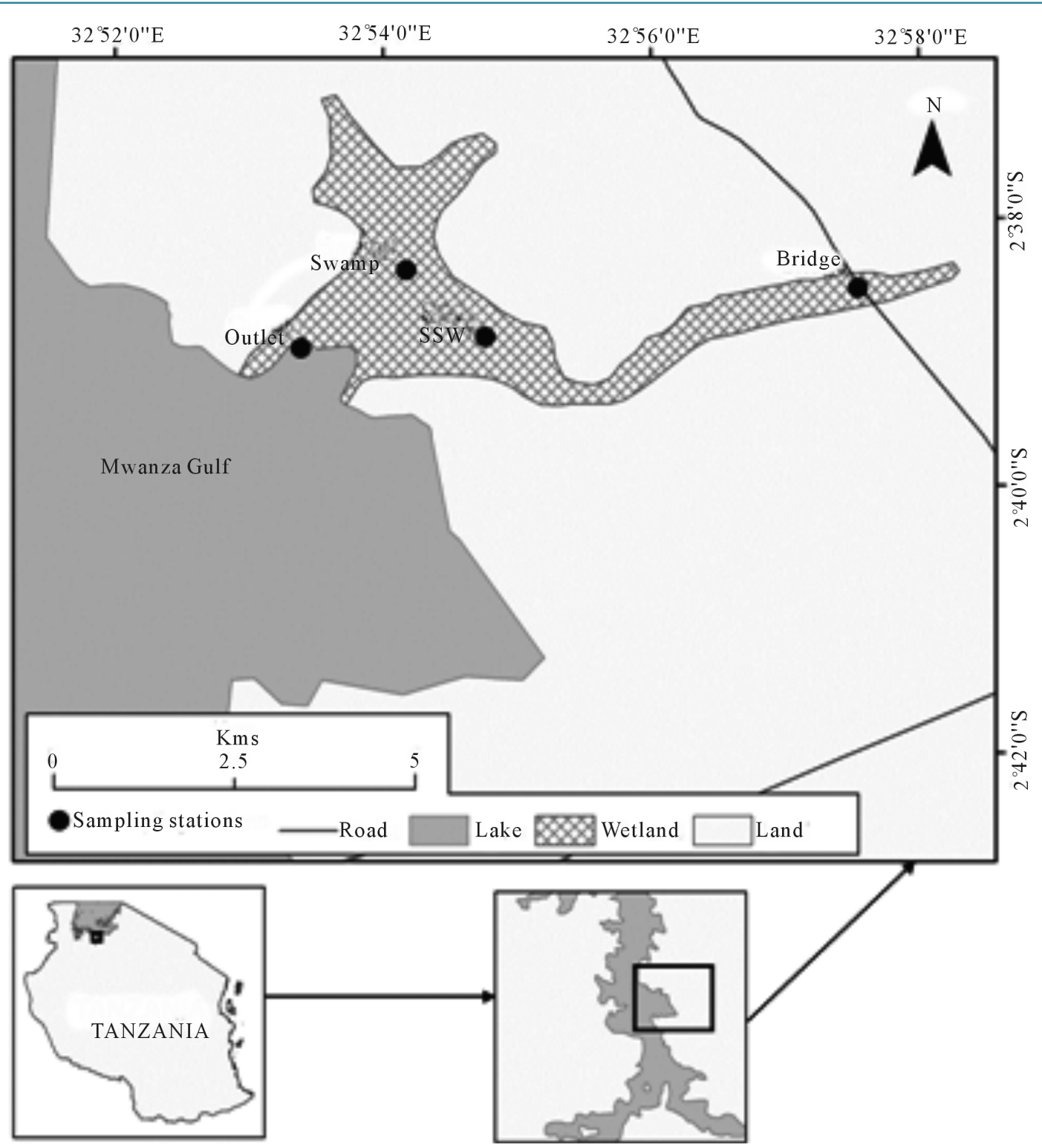

Figure 1. Map of Mwanza gulf of Lake Victoria showing the position of Nyashishi wetland.

Water samples were kept into 1 litre plastic bottles that were pre-cleaned with phosphorus-free detergent, stored in cool boxes with ice and transported to the water quality laboratory in Mwanza for processing. In the Laboratory, turbidity was measured using a turbidimeter, while sub samples for soluble reactive phosphorus analysis were filtered through GF/C and analysed using the ammonium molybdate method (APHA, 2005). Kjeldhal method was used to determine organic nitrogen. Total phosphorus was done by hydrolysation of unfiltered sample using potassium persulphate in order to oxidize all $\mathrm{P}$ compounds to $\mathrm{PO}_{4}-\mathrm{P}$ followed by Ammonium molybdate method determination (APHA, 2005). The ammonium-nitrogen $\left(\mathrm{NH}_{4}-\mathrm{N}\right)$ analysis was based on the formation of indophenol blue. Nitrate $\left(\mathrm{NO}_{3}-\mathrm{N}\right)$ was determined using the Sodium-salycilate method [14] Calorimetric determinations were carried out using a UV-2001 spectrophotometer (Hitachi Ltd, Tokyo, Japan). Percent nutrients removed were calculated according to Equation (1).

$$
\% \text { removed }=\left(\frac{C_{\text {in }}-C_{\text {out }}}{C_{\text {in }}}\right) \times 100
$$

where $C_{\text {in }}$ is the concentration at the inlet $(\mu \mathrm{g} / \mathrm{l}), C_{\text {out }}$ is the concentration at the outlet $(\mu \mathrm{g} / \mathrm{l})$. 


\subsection{Nutrients Uptake by Wetland Macrophyte}

Three plant species which were dominant in the Nyashishi wetland (Eichhornia crassipes, Cyperus papyrus and Typha domingensis) were selected for the nutrient uptake experiment. The experiment consisted of 12 replicates and was run for 28 days. Initial concentrations of $\mathrm{NO}_{3}-\mathrm{N}, \mathrm{NH}_{4}-\mathrm{N}$ and SRP, were determined at the beginning of the experiment. Subsequent samplings were done after two days and after every seven days in order to determine the uptake rate of nutrients. The nutrients uptake rate by the plants were calculated as the difference between measured concentration values and the previous concentration values over the experiment period.

\subsection{Denitrification Experiments}

Denitrification rates were determined at one sampling point, the swamp, which was in the middle of the wetland. Plastic containers of 1 litre capacity were half filled with nearly anoxic water. $20 \mathrm{mg} / \mathrm{l}$ concentration of 1-Allyl-2-thiourea (ATU) was added to the samples to inhibit the nitrification processes. Containers with anoxic water samples were sealed and then inserted into water-filled holes at the site. The experiment was conducted for 24 hours. Denitrification and nitrification were carried out according to Zimmo [4] except that; plastic containers were inserted in sediments instead of PVC's. Denitrification rate was determined by considering the decrease in $\mathrm{NO}_{3}-\mathrm{N}$ concentration over the 24 hours incubation period. The nitrification rates were determined by considering the increase in $\mathrm{NO}_{3}-\mathrm{N}$ concentration over 24 hour's incubation period. Then after, the containers with samples were transferred to the laboratory for final $\mathrm{NO}_{3}-\mathrm{N}$ analyses according to APHA (2005).

\subsection{Nitrification Experiments}

The setup for nitrification experiment was similar to that of denitrification. The only difference between the two setups is that, samples in this experiment were incubated without the nitrification inhibitor 1-Allyl-2-thiourea (ATU) so as to allow the nitrification process to occur along with denitrification. The nitrification rates were determined by considering the increase in $\mathrm{NO}_{3}-\mathrm{N}$ concentration over 24 hour's incubation period.

\subsection{Data Analysis}

Percentage reductions in different physico-chemical parameters were compared using a student T-test to determine seasonal variation (i.e. wet vs. dry season). Comparison for nutrients uptake among the different macrophyte species was performed using a One-Way Analysis of Variance (1-way ANOVA). The data were first tested for homogeneity of variance using a Levene's test, followed by a log transformation prior to analysis whenever homogeneity of variance was not observed. Non parametric test was used when the data were still not normally distributed even after transformation. Statistical significance was measured at $\alpha=0.05$. All analyses were performed using SPSS version 17.

\section{Results}

\subsection{Electrical Conductivity}

The electrical conductivity (EC) at station SSW ranged from $122.4 \pm 4.1 \mu \mathrm{S} / \mathrm{cm}$ to $1107 \mu \mathrm{S} / \mathrm{cm}$ and at station OW the EC values ranged from $109.23 \pm \mu \mathrm{S} / \mathrm{cm}$ to $364.3 \pm 3.6 \mu \mathrm{S} / \mathrm{cm}$ The mean $( \pm \mathrm{SE}$ ) percentage reduction of EC was $47.9 \% \pm 11.1 \%$ (range: $2.3 \%-79.9 \%$ ) in wet season and $74.5 \% \pm 2.6 \%$ (range: $65.5 \%-79.9 \%$ ) in dry season respectively. The lowest percent reductions were observed in May 2008 (2.3\%), but also low percentage values were recorded in April 2008 (13.4\%) and 2009 (18.4\%) respectively. The highest reduction was recorded in October and November - which was the onset of the rain season. There was a significant difference in mean electrical conductivity (EC) reductions between wet and dry seasons with the dry season having higher reductions than wet season $\left(t_{(7.73)}=2.33, p=0.049\right.$, Table 1$)$. Values in dry season were higher and comparable for the whole period (Table 1 ).

\subsection{Turbidity}

Turbidity at station SSW ranged from $12.0 \pm 2.1$ NTU to $156.0 \pm 3.2$ NTU and at station OW the turbidity values ranged from $2.7 \pm 1.4$ NTU to $9.3 \pm 2.1$ NTU. Turbidity decreased, from station SSW to OW by $73 \%$ to 
Table 1. Percentage reduction in values of physical variables and nutrients in Nyashishi wetland during the wet and dry season: $\mathrm{EC}=$ Electrical conductivity, $\mathrm{SRP}=$ soluble reactive phosphorus, $\mathrm{TP}=$ Total phosphorus, $\mathrm{NH}_{3}-\mathrm{N}=$ Ammonia nitrogen, $\mathrm{TN}=$ Total Nitrogen, $\mathrm{NO}_{3}=$ Nitrate.

\begin{tabular}{cccccccc}
\hline Months & EC & Turb. & SRP & $\mathrm{NO}_{3}$ & $\mathrm{TP}$ & $\mathrm{NH}_{3}-\mathrm{N}$ & $\mathrm{TN}$ \\
\hline JAN & 67.05 & 94.85 & 72.88 & 34.09 & 80.76 & 33.38 & 64.77 \\
APRIL & 13.36 & 87.32 & 75.25 & 36.41 & 57.17 & -100.00 & 64.38 \\
MAY & 2.27 & 73.04 & 74.94 & 10.84 & 66.47 & 83.33 & 53.50 \\
JAN & 74.61 & 76.00 & 90.82 & 18.10 & 68.12 & 1.41 & 56.91 \\
APRIL & 18.35 & 95.09 & 89.54 & 56.75 & 76.85 & 75.12 & 44.68 \\
MAY & 56.54 & 81.70 & 91.16 & 65.81 & 79.07 & 12.47 & 59.47 \\
OCT & 79.81 & 80.95 & 80.35 & 26.66 & 69.33 & 66.03 & 12.26 \\
NOV & 71.89 & 88.69 & 98.04 & 47.64 & 95.36 & 91.44 & 69.19 \\
JUN & 65.55 & 92.94 & 95.35 & 52.21 & 91.97 & 83.56 & 55.18 \\
JULY & 72.27 & 93.33 & 94.60 & 49.76 & 90.73 & 84.15 & 60.81 \\
SEPT & 76.81 & 92.21 & 93.65 & 46.32 & 89.31 & 84.74 & 66.97 \\
JUN & 78.17 & 85.71 & 74.28 & 23.91 & 54.22 & 46.06 & -64.71 \\
JULY & 79.86 & 77.78 & 72.47 & 9.73 & 67.80 & 29.04 & -37.45 \\
\hline
\end{tabular}

93.6\% and 50\% to $87 \%$ during the wet and dry seasons respectively. The mean reduction in turbidity did not differ significantly between the wet (mean $\pm \mathrm{SE}=84.7 \% \pm 2.9 \%)$ and dry $(88.4 \$ \pm 3.0 \%)$ seasons $\left(\mathrm{t}_{(11)}=0.84\right.$, $\mathrm{p}$ $=0.42$; Table 1 ), implying that turbidity reduction is not seasons dependent.

\subsection{Soluble Reactive Phosphorus}

Soluble reactive phosphorous ranged from $62.3 \pm 2.8 \mu \mathrm{g} / \mathrm{l}$ to $806.96 \pm 3.9 \mu \mathrm{g} / \mathrm{l}$ at station SSW and from $12.25 \pm$ $1.6 \mu \mathrm{g} / \mathrm{l}$ to $47.46 \pm 2.7 \mu \mathrm{g} / \mathrm{l}$ at $\mathrm{OW}$ station. The percentage reduction was in wet $(84.1 \% \pm 3.3 \%$; range: $72.9 \%$ $98.0 \%)$ and dry (86.1\% $\pm 5.2 \%$; range: $72.5 \%-95.4 \%)$ seasons respectively. However, the differences between seasons were not significant $\left(\mathrm{t}_{(9)}=0.314, \mathrm{p}=0.761\right.$; Table 1 ), probably implying that phosphorus sequestering is an all-time process in the wetland.

\subsection{Total Phosphorus}

Total phosphorus concentration ranged from $126.5 \pm 3.1 \mu \mathrm{g} / \mathrm{l}$ to $1318.8 \pm 4.1 \mu \mathrm{g} / \mathrm{l}$ at station SSW and from $38.79 \pm 2.6 \mu \mathrm{g} / \mathrm{l}$ to $253.76 \pm 3.4 \mu \mathrm{g} / \mathrm{l}$ at the OW station. The mean percentage reduction in Total Phosphorus was comparably similar between seasons $\left(\mathrm{t}_{(11)}=0.60, \mathrm{p}=0.56\right.$; Table 1 ) mean for wet and dry seasons $=74.1 \% \pm$ $4.1 \%$ and $78.8 \% \pm 7.6 \%$ respectively) where high and low values were recorded in both seasons. For example, while higher percent reduction in TP were recorded in November (95.4\%), June (92\%) and July (90.7\%), the lowest reduction were found in April (57.2\%) and June (54.2\%) during the wet and dry seasons respectively.

\subsection{Ammonia}

Ammonia concentration ranged from below detection concentration to $324.7 \pm 3.5 \mu \mathrm{g} / \mathrm{l}$ at station SSW and from $20.7 \pm 2.9 \mu \mathrm{g} / \mathrm{l}$ to $119.1 \pm 3.1 \mu \mathrm{g} / \mathrm{l}$. There was a negative retention in ammonium concentration in April $(100 \%$ release), followed by lowest reduction value of (1.4\%) in January 2008, (12.5\%) in May 2009 and (33.4\%) in January 2009. Highest reduction in wet season was found in November (91.44\%). Percentage reduction during dry season ranged from $29 \%$ (July) to $84.7 \%$ (September) (Table 1). Nevertheless, the differences between wet $(60.6 \% \pm 23.6 \%)$ and dry $(65.5 \% \pm 11.7 \%)$ season were insignificant $\left(\mathrm{t}_{(9)}=0.17, \mathrm{p}=0.87\right)$.

\subsection{Nitrate}

The concentration of nitrate was $99.7 \pm 3 \mu \mathrm{g} / \mathrm{l}$ to $333.4 \pm 3.5 \mu \mathrm{g} / \mathrm{l}$ at SSW station, and $21.35 \pm 2.3 \mu \mathrm{g} / \mathrm{l}$ to $212 \pm$ 
$3.3 \mu \mathrm{g} / \mathrm{l}$ at the OW station The mean percentage nitrate reductions were found to be similar between the wet $(37.04 \% \pm 6.7 \%)$ and dry $(36.4 \% \pm 8.3 \%)$ seasons $\left(t_{(11)}=0.06, p=0.95\right)$. The values ranged from $10.8 \%$ to $65.8 \%$ and from $9.7 \%$ to $52.2 \%$ during the wet and dry season respectively.

\subsection{Total Nitrogen}

Total nitrogen ranged from $594.4 \pm 3.8 \mu \mathrm{g} / \mathrm{l} 1862.4 \pm 3.9 \mu \mathrm{g} / \mathrm{l}$ at SSW station and the concentration at OW ranged from $374.0 \pm 3.6 \mu \mathrm{g} / \mathrm{l}$ to $979.0 \pm 4.0 \mu \mathrm{g} / \mathrm{l} \mathrm{Total}$ nitrogen reduction varied from $12.3 \%$ in October (2009) to $64.8 \%$ in January (2008) during wet season, and negative retentions of $64.7 \%$ and $37.5 \%$ were recorded during the dry season in June and July respectively (Table 1$)$. However, mean values for wet $(57.3 \% \pm 3.1 \%)$ and dry $(16.2 \% \pm 27.8 \%)$ seasons were not significantly different $\left(\mathrm{t}_{(4.10)}=1.47, \mathrm{p}=0.32\right)$.

\subsection{Nutrients Uptake by Wetland Macrophytes}

\subsubsection{Uptake of Soluble Reactive Phosphorus}

The uptake of soluble reactive phosphorus by $C$. papyrus was observed starting from day 2 . The concentration of SRP decreased from $215.15 \pm 2.2 \mu \mathrm{g} / \mathrm{l}$ at the beginning of the experiment to $54.86 \pm 5.92 \mu \mathrm{g} / \mathrm{l}$ on day 28 . The average uptake rate of $C$. Papyrus was estimated at $5.72 \pm 2.03 \mu \mathrm{gl}^{-1} \mathrm{~d}^{-1}$ although the high uptake rates were observed at the beginning of the experiment and decreased at the end of the experiment (see Table 2). Uptake of SRP in E. crassipes treatment decreased from $215.15 \pm 2.2 \mu \mathrm{g} / \mathrm{l}$ at the beginning of experiment to $13.91 \pm 1.4$

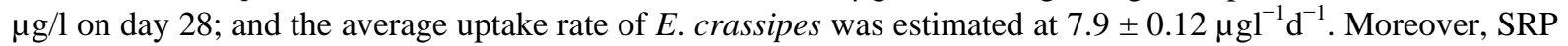
concentration in $T$. domingensis treatment decreased from $215.15 \pm 2.2 \mu \mathrm{g} / \mathrm{l}$ at the beginning of the experiment to $9.54 \pm 3.37 \mu \mathrm{g} / \mathrm{l}$ on day 28 ; and the average uptake rate was estimated at $7.4 \pm 0.07 \mu \mathrm{gl}^{-1} \mathrm{~d}^{-1}$. The control treatment maintained higher SRP levels throughout the experiment period, decreasing from $215.15 \pm 2.2 \mu \mathrm{g} / \mathrm{l}$ at the beginning of experiment to $86.73 \pm 3.25 \mu \mathrm{g} / \mathrm{l}$; and the average uptake rate was estimated at $4.59 \pm 0.12$ $\mathrm{\mu gl}^{-1} \mathrm{~d}^{-1}$. Although SRP concentrations kept decreasing over the experimental period, there were species-specific variations in the uptake rates of the nutrient (Figure 2(a); Table 2). For example, there was some phosphorus production in the E. crassipes treatment on the second day of the experiment (Table 2). A sharp decline in SRP in the E. crassipes and T. domigensis treatments which was observed in the first days of the experiment translate into high uptake rates. A more gradual decline in SRP, which was observed in the control and C. papyrus treatments translate into slow uptake rates (Figure 2(a)). Notwithstanding, a Kruskal-Wallis test showed no significant differences in phosphorus uptake among the three macrophyte species $(\mathrm{KW}=1.220, \mathrm{p}=0.582)$.

\subsubsection{Ammonium Uptake}

Uptake of ammonia in C. papyrus treatment was observed from day 2. The concentration of ammonium decreased from $264.20 \pm 0.21 \mu \mathrm{g} / \mathrm{l}$ at the beginning of the experiment to $41.83 \mu \mathrm{g} / \mathrm{l}$ on day 28 . The estimated average uptake rate of ammonia in C. papyrus was $12.94 \pm 3.42 \mu \mathrm{gl}^{-1} \mathrm{~d}^{-1}$. The ammonia concentration in $E$. crassipes treatment showed a different trend. The concentration decreased from $264.20 \pm 0.21 \mu \mathrm{g} / \mathrm{l}$ at the beginning of the experiment to $27.23 \mu \mathrm{g} / \mathrm{l}$ on day 14 ; and the estimated average uptake rate of ammonia up to day 14 was $13.16 \pm 1.49 \mathrm{\mu gl}^{-1} \mathrm{~d}^{-1}$. A gradual but significant increase in ammonium concentration was observed after the $14^{\text {th }}$ day indicating the generation of ammonia in the treatment system. The $T$. domigensis treatment system showed a similar ammonia uptake trend to that of E. crassipes. The concentration decreased from $264.20 \pm 0.21 \mu \mathrm{g} / \mathrm{l}$ at the beginning of the experiment to $32.8 \mu \mathrm{g} / \mathrm{l}$ on day 21 , and increased again to $53.67 \mu \mathrm{g} / \mathrm{l}$ on day 28. Likewise, the control treatment also started to release ammonium towards the end of the experiment (Figure 2(b); Table 3). The water hyacinth (E. crassipes) showed the highest ammonium uptakes up to day 14 than the rest of the spe-

Table 2. Mean $( \pm \mathrm{SD})$ phosphorus uptake rates $\left(\mu \mathrm{g} / \mathrm{l}^{-1} \cdot \mathrm{d}^{-1}\right)$ by three macrophyte species in Nyashishi Wetland.

\begin{tabular}{cccccc}
\hline Treatments & Day 2 & Day 7 & Day 14 & Day 21 & $0.03 \pm 0.52$ \\
Control & $5.50 \pm 1.51$ & $8.51 \pm 1.20$ & $3.71 \pm 0.90$ & $0.71 \pm 0.61$ & $0.58 \pm 0.70$ \\
E. Craspes & $1.58 \pm 4.52$ & $22.94 \pm 3.13$ & $1.73 \pm 1.26$ & 0.58 & $0.96 \pm 1.12$ \\
C. papyrus & $11.93 \pm 2.49$ & $5.71 \pm 1.87$ & $3.29 \pm 0.87$ & $1.31 \pm 0.10$ \\
T. domigensis & $6.67 \pm 4.25$ & $16.47 \pm 3.13$ & $4.18 \pm 1.71$ & $0.17 \pm 0.03$ \\
\hline
\end{tabular}


Table 3. Mean $( \pm \mathrm{SE})$ ammonium uptake rates $\left(\mu \mathrm{gl}^{-1} \cdot \mathrm{d}^{-1}\right)$ in three macrophyte species from the Nyashishi Wetland.

\begin{tabular}{cccccc}
\hline Treatments & Day 2 & Day 7 & Day 14 & Day 21 & Day 28 \\
\hline Control & $13.40 \pm 3.47$ & $10.30 \pm 2.19$ & $3.30 \pm 1.90$ & $0.09 \pm 0.20$ & $1.46 \pm 1.15$ \\
E. craspes & $51.41 \pm 2.03$ & $14.28 \pm 0.0$ & $2.44 \pm 0.71$ & $-0.48 \pm 0.32$ & $-2.4 \pm 1.08$ \\
C. Papyrus & $12.94 \pm 3.01$ & $9.40 \pm 2.24$ & $6.98 \pm 0.37$ & $1.58 \pm 1.04$ & $0.01 \pm 0.85$ \\
T. Domigensis & $15.09 \pm 2.76$ & $11.19 \pm 1.51$ & $6.26 \pm 1.31$ & $1.67 \pm 0.58$ & $-0.74 \pm 0.04$ \\
\hline
\end{tabular}

cies and control (Figure 2(b); Table 3). T. domigensis and C. papyrus showed comparable uptake rates (Table 3). There was however, no significant differences in uptake rates among the macrophyte species (One way ANOVA, $\left.\mathrm{F}_{(5)}=0.164, \mathrm{p}=0.85\right)$.

\subsubsection{Nitrate Uptake}

Nitrate concentration in E. crassipes treatment decreased from the initial concentration of $105.20 \pm 0.0 \mu \mathrm{g} / \mathrm{l}$ to $63.53 \pm 1.89 \mu \mathrm{g} / \mathrm{l}$ on the second day. The nitrate concentration in the E. crassipes treatment increased sharply to the highest $(330.27 \pm 8.53 \mu \mathrm{g} / \mathrm{l})$ on the $21^{\text {th }}$ day of the experiment (Figure 2(c)). Concentration of nitrate in $C$. papyrus treatment decreased from the initial concentration of $105.20 \pm 0.0 \mu \mathrm{g} / \mathrm{l}$ to $69.80 \pm 1.91 \mu \mathrm{g} / \mathrm{l}$ on the second day. After that, a significant increase was observed on the $21^{\text {st }}$ day $(136.23 \pm 5.55 \mu \mathrm{g} / \mathrm{l})$. Likewise, the concentration in T. domingensis treatment decreased from the initial concentration of $105.20 \pm 0.0 \mu \mathrm{g} / \mathrm{l}$ to 70.98 $\pm 2.58 \mu \mathrm{g} / \mathrm{l}$ on the $2^{\text {nd }}$ day. Then there was a significant increase to $261.34 \pm 0.74 \mu \mathrm{g} / \mathrm{l}$ on day 21 (Figure 2(c)).

\subsection{Nitrification and Denitrification in the Wetland Sediments}

The denitrification and nitrification rates of the Nyashishi wetland are given in Table 4. Denitrification rate ranged between $0.02 \pm 0.02 \mu \mathrm{gl}^{-1} \mathrm{~d}^{-1}$ and $0.082 \pm 0.01 \mu \mathrm{gl}^{-1} \mathrm{~d}^{-1}$ with an average value of $0.059 \pm 0.16 \mu \mathrm{gl}^{-1} \mathrm{~d}^{-1}$. Nitrification was also very low and negative net nitrification rates were encountered. While the lowest denitrification value of $0.024 \pm 0.02 \mu \mathrm{gl}^{-1} \mathrm{~d}^{-1}$ was encountered in April 2008; the maximum $\left(0.140 \pm 0.21 \mu \mathrm{gl}^{-1} \mathrm{~d}^{-1}\right)$ and

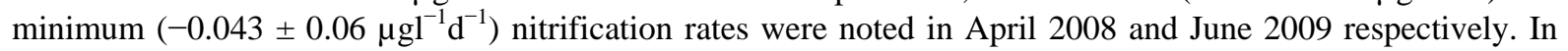
this study, denitrification rates showed no definite pattern over time, while nitrification showed a slight increase (Table 4).

\subsection{Comparison of Nutrients Consumed by Macrophyte Species in the Treatments}

Comparison was made among plant species to see which species exhibited higher uptake rates (Figure 3). Water hyacinth (Eichhornia crassipes) showed the highest reduction of nitrate-nitrogen which was available in the treatment containers (31\%), followed by Cyperus papyrus (26\%). Percentage reduction in Typha domingensis was comparable with reduction in the control containers (Figure 2). Water hyacinth still exhibited the highest percentage reduction for nitrite-nitrogen (43\%), followed by Typha domingensis (33\%), while Cyperus papyrus showed the lowest performance (24\%). However, there was no reduction in the control containers. Likewise, Eichhornia craspes was the most efficient in phosphorus reduction as $54 \%$ of the available soluble reactive phosphorus was noticed, followed by Typha domingensis (37\%) and the lowest reduction was observed in the Cyperus papyrus containers (7\%). In the control treatments, only $2 \%$ was reduced. Similarly, the same trend was observed for ammonia-nitrogen whereby 40\% reduction was recorded in Eichhornia craspes containers, followed by $22 \%$ in $T$. domigensis containers. The percentage reduction in Cyperus papyrus and control containers was comparable (Figure 3).

\section{Discussions}

The results indicate that, there was reduction in most of the parameters as water passed through the Nyashishi wetland, although the retention capacity was different according to seasons. The higher reduction of electrical conductivity in the dry season is caused by the low flushing of effluents in the wetland which normally increases due to runoff in the rain season. During the dry season there is low volume of water in the river, thus reduced water flow. This situation allows suspended matter (i.e. detritus) to settle to the bottom, improving nutrient removal mechanisms. Moreover, at the inlet point, there is pool of water which is used for animal watering espe- 
Table 4. Mean $( \pm \mathrm{SE})$ for four measurements of denitrification and nitrification rates $\left(\mu \mathrm{gl}^{-1} \cdot \mathrm{d}^{-1}\right)$ at station WW in Nyashishi wetland.

\begin{tabular}{ccc}
\hline Experiment & Denitrification rate & Nitrification rate \\
Experiment 1 & $0.024 \pm 0.02$ & $-0.043 \pm 0.06$ \\
Experiment 2 & $0.082 \pm 0.01$ & $-0.025 \pm 0.01$ \\
Experiment 3 & $0.058 \pm 0.02$ & $-0.017 \pm 0.00$ \\
Experiment 4 & $0.074 \pm 0.02$ & $0.14 \pm 0.21$ \\
\hline
\end{tabular}
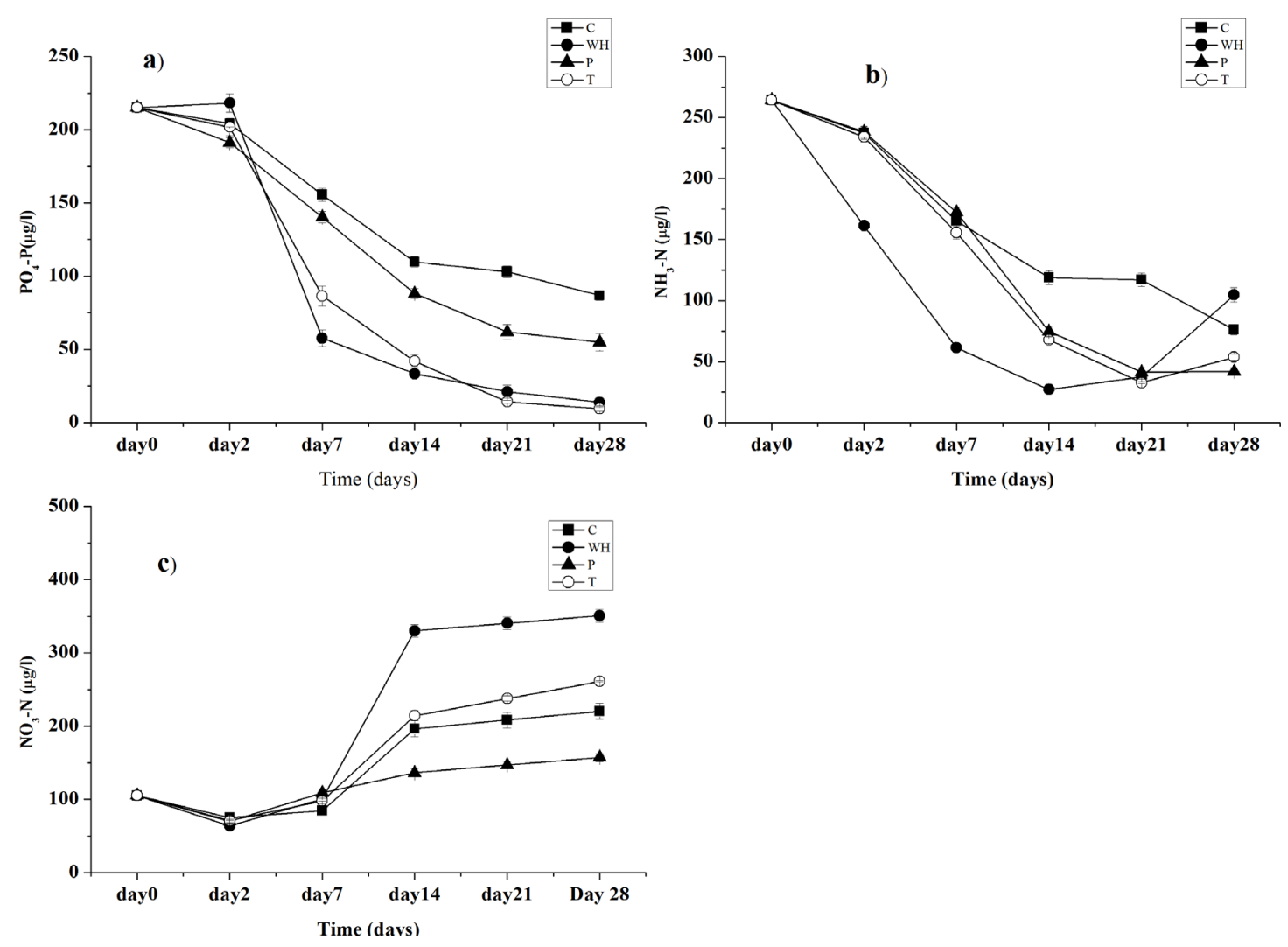

Figure 2. Change in (a) soluble reactive phosphorus (b) Ammonia and (c) nitrate concentration in three experimental macrophyte species. $\mathrm{C}=$ control; $\mathrm{WH}=$ water hyacinth $($ E. crassipes $) ; \mathrm{P}=$ Cyperus papyrus; $\mathrm{T}=$ Typha domigensis.

cially during the dry season. During the dry season the water flow diminishes to a standstill in some years, and due to higher evaporation, there is higher nutrients concentration. The decrease in water flow might have contributed to the higher reduction in electrical conductivity especially in November and December. These months in Mwanza region are the onset of the rainy season, so the water volume was still low.

The reduction in the levels of turbidity along the wetland was manifested in both seasons. The reason is due to huge swampy areas in the wetland made of several species of wetland macrophyte, such as Cyperus papyrus L. and Phragmites mauritianus (Kunth). The extensively interlaced but permeable root mat of papyrus effectively retained suspended organic particles which provided sufficient substrates for the proliferation of heterotrophic bacteria as also stated by [7]. In so doing it makes wetland systems to work as giant filters, by removing suspended solids, and dissolved nutrients pollutants from the water before it enters the lake [15]. Moreover, macrophyte reduces turbidity using their root hairs which have electrical charges that attract opposite charges of colloidal particles. When suspended solids with opposite charges pass through the root hairs, they adhere onto the roots. Consequently, they are slowly assimilated by the plant and microorganisms [16].

Phosphorus species analysed (SRP and TP) were retained in the wetland throught the year both in the wet and 


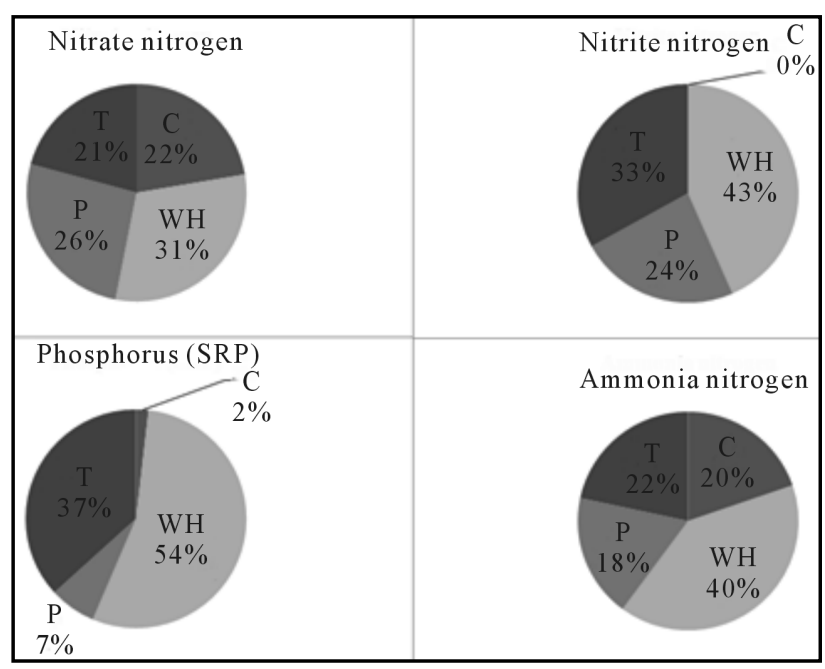

Figure 3. Comparison on different nutrients reduction percentages in the studied macrophyte species. $\mathrm{C}=$ Control; $\mathrm{T}=\mathrm{Ty}$ pha domigensis; $\mathrm{WH}=$ Water hyacinth; $\mathrm{P}=$ Cyperus papyrus.

dry season. This was probably due to attachment of colloidal particles to root hairs as well as uptake by macrophytes as also stated by [17]. The retention of phosphorus in the wetland was supported by laboratory experiments on nutrients uptake by wetland plants whereby; the decrease in phosphorus species was recorded in all experimental treatments. The high productivity of macrophytes enables substantial amount of nutrients to be stored in plant biomass.

Ammonia exhibited a negative retention especially in April during the peak of the rain season, and other retention was observed in September and November. The negative retention is explained by high rate of flushing due to the high flow rate of water through the wetland. Moreover, higher concentration of ammonia was recorded in the lake during the same season, suggesting that other chemical/biological activities were taking place in the system. But also, the increase might have been caused by decomposition of organic matter brought by runoff into the wetland which used up available oxygen in the sediment and thus nitrification process ceased. These findings are supported by [18] who stated that, at relatively low dissolved oxygen, nitrification of ammonia ceases and the absorptive capacity of the sediments is reduced. This causes a marked increase of the release of ammonium from the sediments.

Nutrients release from the wetland was also recorded for TN in June and July; this indicates that the wetland does not effectively retain TN. Similar findings were reported by [19] Their study demonstrated that, the wetland had a negative retention of total nitrogen, and this was associated with the large export of organic nitrogen produced in the wetland. Findings from Kirinya wetland in Uganda, showed a low retention of nitrogen such that; $75 \%$ of the nitrogen flowing into the wetland flowed out into the lake and only $25 \%$ was retained [15].

In the experiment on nutrients uptake by wetland plants, phosphorus decreased in all treatments, even in the controls without plants. The phosphorous removal was not only by the macrophyte, as it has been also observed by [20] and [21]. This suggests the importance of biological removal for sewage treatment in constructed and sedimentation ponds apart from chemical precipitation by alum or lime in conventional sewage treatment plants [20].

The nutrients uptake experiments demonstrated that, E. Crassipes was the most efficient plant in phosphorus reduction as $54 \%$ of the available soluble reactive phosphorus was uptaken, compared to $37 \%$ by Typha domingensis and only $7 \%$ of Cyperus papyrus. The higher uptake rate by E. Crassipes was due to relatively higher growth rate of the plant as compared to the other two plant species [22]. E. Crassipes can double within a short time; say 6 days (Mitchell, 1976). Moreover, E. crassipes has also extensive root system which has excellent filtration and high bacterial density. The root system provide surface onto which bacteria grow; provide media for filtration and adsorption of solids and in some cases release natural polymers that facilitate flocculation and sedimentation [23]. The other two species showed less absorption capacity because the submerged portions of their stems has less filtration and bacterial density than the roots of floating plants like E. crassipes [23]. 
The reduction in ammonium concentration was observed in all treatments including the control, from the observation it can be inferred that, apart from uptake by plants, a certain amount of ammonium may have been oxidized to other forms of $\mathrm{N}$, otherwise, the difference would have been less in the containers with no plants. This conclusion is backed by the nitrate results which showed an increase in nitrate concentration in all treatments instead of removal.

Like other nutrients, uptake of both ammonium and nitrate were slightly higher for E. crassipes than in the other plant species, due to its high growth rate than the two species as described above. These findings are in agreement with the results by [24] who obtained higher values of phosphorus and nitrogen nutrients uptake in $E$. crassipes than Pistia stratiotes in the Pantanal, Brazil.

Although bacterial nitrification-denitrification is thought to be the dominant cause of nitrogen removal from the wetland soils, [25], generally in this study the rates were low. This is because, the amount of oxygen transferred to the wetlands through macrophyte roots and atmospheric diffusion is relatively small compared to the amount of oxygen required to oxidize ammonia due to the dense vegetation cover of papyrus which tends to limit atmospheric aeration and oxygen production by algal photosynthesis; hence less nitrate is available to undergo the denitrification process e.g. [7] [26]. Similarly, [15] concluded that, denitrification did not have a significant contribution in the nitrogen budget due to the minor importance of nitrate in the system. Concurrently, [19] also stated that, denitrification was of minor importance on the influence of nitrate in Nyashishi wetland.

\section{Conclusion}

According to the results of this study, plants nutrients uptake demonstrated to be the dominant nutrients removing mechanism in the Nyashishi wetland system. Among the wetland macrophytes, E. Crassipes was the most efficient in nutrients removal as compared to Typha domingensis and Cyperus papyrus. However, apart from the macrophytes, the nutrients uptake experiment showed that, microorganisms and algae also remove the nutrients. Moreover, it is important to note that, this "locking" of nutrients in aquatic macrophytes is only short-term because of the rapid turnover especially for water hyacinth. If plants are not harvested, the dead tissues decompose rapidly and release nutrients back into the water. Frequent harvesting of the biomass is therefore recommended and is necessary for complete removal of nutrients from the wetland system. Since the nutrients uptake is high despite the relatively short life of the plant, this is an advantage for wetland management. This ability can be exploited in removing excess nutrients from runoff by frequent harvesting of the mature plants.

\section{References}

[1] Kelderman, P., Kansiime, F., Tola, M.A. and VanDam, A. (2007) The Role of Sediments for Phosphorus Retention in the Kirinya Wetland (Uganda). Wetlands Ecology and Management, 15, 481-488.

[2] Kansiime, F., Saunders, M.J. and Loiselle, S.A. (2007) Functioning and Dynamics of Wetland Vegetation of Lake Victoria: An Overview. Wetland Ecology Management, 15, 443-451. http://dx.doi.org/10.1007/s11273-007-9043-9

[3] Mugisha, P., Kansiime, F., Mucunguzi, P. and Kateyo, E. (2007) Wetland Vegetation and Nutrient Retention in Nakivubo and Kirinya Wetlands in the Lake Victoria Basin of Uganda. Physics and Chemistry of the Earth, Parts A/B/C, 32, 1359-1365. http://dx.doi.org/10.1016/j.pce.2007.07.040

[4] Zimmo, O. (2003) Nitrogen Transformations and Removal Mechanisms in Algal and Duckweed Waste Stabilisation Ponds Thesis, Wagengen University, Delft, the Netherlands.

[5] Mayo, A.W. and Bigambo, T. (2005) Nitrogen Transformation in Horizontal Subsurface Flow Constructed Wetlands I: Model Development. Physics and Chemistry of the Earth, Parts A/B/C, 30, 658-667. http://dx.doi.org/10.1016/j.pce.2005.08.005

[6] Senzia, M.A., Mashauri, D.A., Mayo, A.W., Mbwette, T.S.A. and Jorgense, S.E. (2002) Modelling Nitrogen Transformation in Horizontal Subsurface Flow Constructed Wetlands Planted with Phragmites Mauritiunius. 8th International Conference on Wetlands Systems for Water Pollution Control, Arusha, Tanzania, 813-827.

[7] Kyambadde, J. (2005) Optimizing Processes for Biological Nitrogen Removal in Nakivubo Wetland, Uganda. Ph.D. Thesis, AlbaNova University Centre.

[8] Verschuren, D., Johnson, T.C., Kling, H.J., Edgington, D.N., Leavitt, P.R., Brown, E.T., Talbot, M.R. and Hecky, R.E. (2002) History and Timing of Human Impact on Lake Victoria, East Africa. Proceedings of the Royal Society Biological Sciences Series B, 269, 289-294

[9] Odada, E.O., Olago, D.O., Kulindwa, K., Ntiba, M. and Wandiga, S. (2004) Mitigation of Environmental Problems in 
Lake Victoria, East Africa: Causal Chain and Policy Options Analysis. AMBIO, 33, 13-23.

[10] Scheren, P.A.G., Zanting, M.H.A. and Lemmens, A.M.C. (2000) Estimation of Water Pollution Sources in Lake Victoria, East Africa: Application and Elaboration of the Rapid Assessment Methodology. Journal of Environmental Management, 58, 235-248. http://dx.doi.org/10.1006/jema.2000.0322

[11] Lake Victoria Environmental Management Project Phase (LVEMP). (2002) Water Quality and Ecosystem Management Component, Preliminary Findings of Studies Conducted on Lake Victoria.

[12] Hecky, R.E. (1993) The Eutrophication of Lake Victoria. Verhandlungen der Internationalen Vereinigung für Theoretische und Angewandte Limnologie, 25, 39-48.

[13] Guildford, S.J. and Hecky, R.E. (2000) Total Nitrogen, Total Phosphorus and Nutrient Limitation in Lakes and Oceans: Is There a Common Relationship? Limnology and Oceanography, 45, 1213-1223. http://dx.doi.org/10.4319/lo.2000.45.6.1213

[14] Müller, R. and Wiedemann, O. (1955) Die Bestimmung des Nitrations im Wasser. Vom Wasser, 22, 247-271.

[15] van Dam, A.A., Dardona, A., Kelderman, P. and Kansiime, F. (2007) A Simulation Model for Nitrogen Retention in a Papyrus Wetland Near Lake Victoria, Uganda (East Africa). Wetlands Ecology and Management, 15, 469-480. http://dx.doi.org/10.1007/s11273-007-9047-5

[16] Dhote, S. and Dixit, S. (2009) Water Quality Improvement through Macrophytes-A Review. Environmental Monitoring and Assessment, 152. 149-153. http://dx.doi.org/10.1007/s10661-008-0303-9

[17] Squires, M.M. and Lesack, L.F.W. (2003) The Relation between Sediment Nutrient Content and Macrophyte Biomass and Community Tructure along a Water Transparency Gradient Mong Lakes of the Mackenzie Delta. Canadian Journal of Fisheries and Aquatic Sciences, 60, 333-344. http://dx.doi.org/10.1007/s10661-008-0303-9

[18] Wetzel, R.G. (2001) Limnology. Saunders College Publishing, San Diego.

[19] Mwanuzi, F., Aalderink, H. and Mdamo, A. (2003) Simulation of Pollution Buffering Capacity of Wetlands Fringing the Lake Victoria. Environmental International, 29, 95-103. http://dx.doi.org/10.1016/S0160-4120(02)00150-2

[20] Stratful, I., Brett, S., Scrimshaw, M.B. and Lester, J.N. (1999) Biological Phosphorus Removal, Its Role in Phosphorus Recycling. Environmental Technology, 20, 681-695. http://dx.doi.org/10.1080/09593332008616863

[21] Krishnaswamy, U., Muthusamy, M. and Perumalsamy, L. (2009) Studies on the Efficiency of the Removal of Phosphate Using Bacterial Consortium for the Biotreatment of Phosphate Wastewater. European Journal of Applied Sciences, 1, 06-15.

[22] Brix, H. (1993) Macrophytes-Mediated Oxygen Transfer in Wetlands: Transport Mechanism and Rate In: Moshiri, G.A. and Arbor, A., Eds., Constructed Wetlands for Water Quality Improvement, Lewis, London.

[23] Abassi, T. and Abbasi, S.A. (2010) Factors Which Facilitate Waste Water Treatment by Aquatic Weeds-The Mechanism of the Weeds. International Journal of Environmental Studies, 67, 349-371. http://dx.doi.org/10.1080/00207230902978380

[24] Abdo, M.S.A. and Da Silva, C.J. (2000) Nutrient Stock in the Aquatic Macrophytes Eichhornia Crassipes and Pistia Stratiotes in the Pantanal-Brazil. German-Brazilian Workshop on Neotropical Ecosystems-Achievements and Prospects of Cooperative Research. Hamburg.

[25] Russell, J.M., Vanoostrom, A.J. and Lindsey, S.B. (1994) Denitrifying Sites in Constructed Wetlands Treating Agricultural Industry Wastes. Environmental Technology, 15, 95-99. http://dx.doi.org/10.1080/09593339409385408

[26] Wu, M., Franz, E.H. and Chen, S. (2001) Oxygen Fluxes and Ammonia Removal Efficiencies in Constructed Treatment Wetlands. Water Environmental Research, 73, 661-666. http://dx.doi.org/10.2175/106143001X143394 